\title{
Removal of precursors of disinfection byproducts by hybrid ferrihydrite adsorption-membrane filtration process
}

\author{
Hideki OSAWA $^{1}$, Jenyuk LOHWACHARIN ${ }^{1}$ and Satoshi TAKIZAWA ${ }^{1}$ \\ ${ }^{1}$ Department of Urban Engineering, Graduate School of Engineering, The University of Tokyo, \\ (7-3-1 Hongo, Bunkyo-ku, Tokyo 113-8656, Japan) \\ E-mail: osawa@env.t.u-tokyo.ac.jp, jenyuk@env.t.u-tokyo.ac.jp, takizawa@env.t.u-tokyo.ac.jp
}

\begin{abstract}
This study aimed to compare the removal rates of precursors of disinfection byproducts (DBPs) by ferrihydrite (FH) and powdered activated carbon (PAC) in the hybrid adsorption-microfiltration (MF) processes. The formation potentials of trihalomethanes and haloacetonitriles (DBPFPs) and characteristics of dissolved organic matter (DOM) from drinking water sources having different contents of aromatic DOM and bromide, were evaluated before and after the FH+MF or PAC+MF treatments. It was found that the DOM characteristics influenced significantly on their removal rates; namely, the FH+MF process lowered DBPFP in waters containing aromatic DOM by mainly removing precursors of chlorinated DBPs, whereas brominated DBPs increased after FH+MF due to higher Br/DOC ratios caused by residual bromide. The PAC+MF process was more effective than the FH+MF process in removal of low molecular weight (MW) hydrophilic DOM, which was a precursor of dichloroacetonitrile. In addition to DOM characteristic (i.e. MW, aromaticity), an inorganic precursor (i.e. bromide) also had significant effects on DBP yields and bromine substitution. When bromide was abundant in water, bromine appeared to be more effectively incorporated into low UV-absorbing (i.e. less aromatic) DOM fractions and simple structural DBPs.
\end{abstract}

Key Words: Disinfection byproducts, ferrihydrite, haloacetonitriles, microfiltration

\section{INTRODUCTION}

Chlorine is widely used as disinfectant, but it reacts with natural organic matter $(\mathrm{NOM})$ in water to produce disinfection byproducts (DBPs), which have been reported to pose potential health risks to humans ${ }^{1)}$. Trihalomethanes (THMs) are commonly detected DBPs in chlorinated water and they are regulated in many countries including Japan. Their brominated analogues (i.e. brominated DBPs; $\mathrm{Br}$-DBPs) are formed in the presence of bromide ion $\left(\mathrm{Br}^{-}\right)$in water ${ }^{2}$. There are growing interests in controlling Br-DBPs because they are reported to be much more toxic compared to chlorinated $\mathrm{DBPs}^{3)}$. Nitrogenous DBPs (N-DBPs) such as haloacetonitriles (HANs) are also of emerging concerns because they are more toxic compared to regulated THMs or haloacetic acids (HAAs) ${ }^{4}$.

DBP formation and speciation mechanism are complicated because they depend on many factors such as NOM characteristics, water matrices and chlorination conditions ${ }^{5-7)}$. The presence of bromide ions makes the DBP formation more complicated because bromide to dissolved organic carbon ratios $(\mathrm{Br} / \mathrm{DOC})$ or bromide to chloride ratio $(\mathrm{Br} / \mathrm{Cl})$ influence speciation of DBP formation ${ }^{2,8}$. It has been reported that chlorine and bromine are very reactive against phenolic moieties of NOM through either electron transfer, potentially forming quinonic structures or electrophilic aromatic substitution processes, which incorporate halogen ${ }^{9}$. The authors reveal that the bromide concentration is a key factor for driving these processes; however, the reaction of bromine with NOM has not yet been elaborated with natural water matrices.

NOM characteristics are keys to predict and control the DBP formation. The precursors of DBPs are reported to be mainly hydrophobic $\mathrm{NOM}^{10)}$ although there are recent publications suggesting that hydrophilic fractions also contribute to DBP formation significantly ${ }^{11,12)}$. Specific UV absorbance $\left(\mathrm{SUVA}_{254}\right)$ is a widely used quantitative indicator of hydrophobicity or aromaticity, which is defined as the UV absorbance at $254 \mathrm{~nm}$ normalized by the 
DOC concentration. Since the aromatic fraction contains major precursors of DBPs, $\mathrm{SUVA}_{254}$ correlates well with DBP formation and then is commonly used as a surrogate for predicting DBP formations ${ }^{6,10,13)}$. SUVA 254 also serves as an indicator of brominated DBP species, because hypobromous acid $(\mathrm{HOBr})$ is more reactive towards hydrophilic fractions of NOM to produce Br-DBPs. A previous study revealed the relationships between SUVA $_{254}$ and bromine incorporation in the THM and HAA formations, though not much are yet known in other DBPs ${ }^{13)}$.

Although many studies are conducted to find the factors affecting the DBP formations, most of them are performed using DOM surrogate compounds or under controlled conditions by fractionating DOM using resins or ultrafiltration ${ }^{13-15}$. This might not represent the actual DOM characteristics of treated water by treatment processes such as adsorption. In addition, many researchers have focused on regulated DBPs such as THMs and HAAs and their precursors, but the formation of emerging DBPs such as HANs is not well understood.

We aimed in this study to delineate the DOM characteristics and their DBP formation potential (DBPFP) after adsorption by powdered activated carbon (PAC) or ferrihydrite (FH). $\mathrm{FH}$ is an amorphous iron oxide particle with chemical formula of $\mathrm{Fe}(\mathrm{OH})_{3} \cdot \mathrm{nH}_{2} \mathrm{O}^{16)}$ or $\mathrm{Fe}_{10} \mathrm{O}_{14}(\mathrm{OH})_{2}{ }^{17)}$. Adsorption treatment using $\mathrm{FH}$ is drawing attention in controlling DBPs because of its large surface areas and high affinity towards aromatic $\mathrm{DOM}^{18}$, which is the main DBP precursor. In this study, the adsorption treatments were integrated with microfiltration (MF) process (hereafter referred to as a hybrid process). Coupling membrane technology with adsorption process (i.e. hybrid process) has become popular because it can lower DBPs by removing DOM while simultaneously rejecting nearly all pathogenic bacteria and colloidal particles $^{19-22}$.

Therefore, the objectives of this study were to (i) evaluate the effectiveness of the hybrid processes combining the MF with PAC or FH adsorption in removal of DOM and reductions in DBPFPs, (ii) assess the characteristics of DOM and their DBPFPs after the treatment by the hybrid processes, and (iii) evaluate the use of $\mathrm{SUVA}_{254}$ as the indicator of bromine incorporation into DBPs, especially in THMs and HANs.

\section{MATERIALS AND METHODS}

\section{(1) Source waters and fractionation}

We collected water samples in the Ogasawara Islands, a group of sub-tropical islands located ca.
$1000 \mathrm{~km}$ south of Tokyo (Japan) in October 2014: from two reservoirs in Chichijima Island (i.e. CH1 and $\mathrm{CH} 2$ ) and from one reservoir in Hahajima Island (i.e. HA). Another water sample (AR) was collected from the downstream of Arakawa River in Saitama prefecture as a representative of the raw water used for potable purpose in the mainland of Japan.

The water samples were pre-filtered through hydrophilic PTFE membranes with a nominal pore size of $0.45 \mu \mathrm{m}$ (Millipore, JHWP09025) to remove particulate material, hereafter referred to as raw waters, and stored in the dark at $4{ }^{\circ} \mathrm{C}$ until use.

A regenerated cellulose (RC) membrane (Millipore, PLBC15005) was used to fractionate the raw water into molecular weight $(\mathrm{MW})>3 \mathrm{kDa}$ and MW < 3kDa fractions by the method used in the previous publication ${ }^{23)}$. The retentate and permeate were analyzed for DOC concentrations.

\section{(2) Preparation of adsorbents}

The FH and PAC used in this study were prepared by the following methods.

The 2-line FH was synthesized following the method proposed by Leone et al. (2001) ${ }^{24)}$ and Yang et al. $(2012)^{25)}$. The stock solution of FH was sonicated at $80 \mathrm{~W}$ for $10 \mathrm{~min}$ (Branson Sonifer 450, Branson, USA) before storage. Volumetric mean diameter of sonicated $\mathrm{FH}$ was $0.15 \mu \mathrm{m}$ based on the dynamic light scattering analysis (Nanotrac ${ }^{\mathrm{TM}} 150$, Nikkiso, Japan). The FH concentration was quantified by inductivity coupled plasma mass spectrometry (ICP-MS) after the digestion with nitric $\operatorname{acid}^{26)}$. One milligram of dried $\mathrm{FH}$ corresponds to $0.59 \mathrm{mg}$ of total $\mathrm{Fe}$.

The activated carbon used in this study (Shirasagi S-10, Japan EnviroChemicals. Ltd., Japan) was obtained from a full-scale water treatment plant in Japan. Based on the manufacturer's catalogue, this PAC has a mean particle size of $151.2 \mu \mathrm{m}$. It was cleaned before use following Lohwacharin et al. $(2010)^{27)}$. To negate the effect of the particle sizes, the adsorption capacity of two adsorbents was determined on the surface area basis.

The BET surface area and the mean pore diameter were determined based on the nitrogen adsorption method using BELSORP-mini II (BEL Japan Inc.) as shown in Table 1 . The BET surface area of synthesized FH was $315 \mathrm{~m}^{2} / \mathrm{g}$, which was greater than that of $3.5 \mu \mathrm{m} \mathrm{FH}$ particles $\left(244 \mathrm{~m}^{2} / \mathrm{g}\right)$ used in Kang and Choo $(2010)^{28)}$.

Table 1 Key properties of adsorbents used in this study.

\begin{tabular}{cccc}
\hline Adsorbents & $\begin{array}{c}\text { Mean particle } \\
\text { size }(\mu \mathrm{m})\end{array}$ & $\begin{array}{c}\text { BET surface } \\
\text { area }\left(\mathrm{m}^{2} / \mathrm{g}\right)\end{array}$ & $\begin{array}{c}\text { Average pore } \\
\text { diameter }(\mathrm{nm})\end{array}$ \\
\hline FH & 0.19 & $315 \pm 3$ & $2.27 \pm 0.02$ \\
\hline PAC & 151.2 & $875 \pm 2$ & $0.86 \pm 0.01$ \\
\hline
\end{tabular}




\section{(3) Hybrid FH+MF and PAC+MF processes}

The lab-scale M F system are described in detail in our previous publications ${ }^{25,29)}$. A hydrophilic PVDF membrane with a nominal pore size of 0.10 $\mu \mathrm{m}$ and an effective surface area of $13.4 \mathrm{~cm}^{2}$ (VVLP09050, Millipore) was used to ensure adsorbent separation. To begin, FH or PAC was dosed into the stirred filtration cell at the same dosage of $1 \mathrm{~g} / \mathrm{L}$ as Fe or PAC. Filtration was operated at a constant trans-membrane pressure (TMP) of $50 \pm 1 \mathrm{kPa}$ and a stirring rate of $600 \mathrm{rpm}$ till a permeate volume of $450 \mathrm{~mL}$.

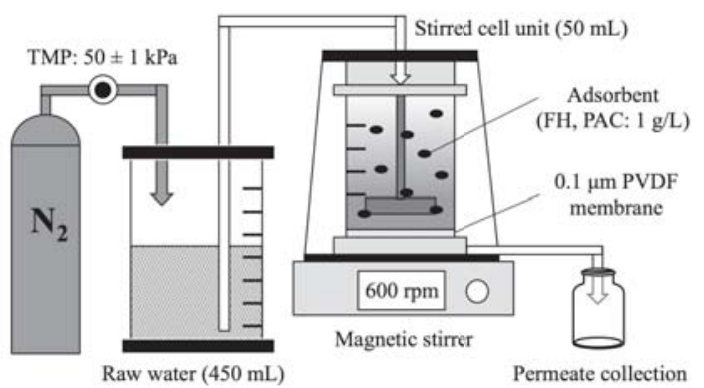

Fig. 1 Schematic diagram of the hybrid M F process.

\section{(4) DBP formation potential (DBPFP)}

Chlorination was performed by dosing sodium hypochlorite into water samples buffered at $\mathrm{pH} 7.0$ \pm 0.2 using $10 \mathrm{mM}$ phosphate buffer, followed by 24 hour incubation in the dark at $20^{\circ} \mathrm{C}$. The applied initial free chlorine dose was calculated as DOC $\times$ $1.5+1.0(\mathrm{mg} / \mathrm{L})$ following the preliminary chlorine demand experiments on raw water samples. The residual free chlorine was confirmed to be at 1-2 $\mathrm{mg} / \mathrm{L}$ by the DPD method using a colorimeter. A fter the incubation, samples were dechlorinated following the JWWA Standard Methods and USEPA 551.1 methods $^{30,31)}$.. Four THM s, namely chloroform (TCM), dibromochloromethane $(\mathrm{DBCM})$, bromodichloromethane (BDCM) and bromoform (TBM) were determined with a gas chromatography-electron capture detector (GC-ECD), according to the JWWA Standard Methods ${ }^{30}$. Three haloacetonitriles, trichloroacetonitrile (TCAN), dichloroacetonitrile (DCAN) and dibromoacetonitrile (DBAN) were extracted with pentane using the USEPA 551.1 methods and determined by the methods described in the following section.

\section{(5) Analytical methods}

DOC and total dissolved nitrogen (TDN) concentrations were measured using a total organic carbon (TOC) analyzer (TOC-L, Shimadzu, Japan) equipped with the total nitrogen unit (TNM-L,
Shimadzu, Japan). UV absorbance at $254 \mathrm{~nm}$ $\left(U V_{254}\right)$ was measured with an UV/Vis spectrophotometer (UV-2000, Hitachi, Japan). Nitrite, nitrate and bromide concentrations were analyzed with an ion chromatography analyzer (M etrohm 861, M etrohm, Switzerland).

THM s were analyzed by the head-space method following Phetrak et al. $(2016)^{30,32)}$ HANs were analyzed using a gas chromatography-electron capture detector (GC-ECD) (GC-2010 plus, Shimadzu Corp., Japan) with a Rtx ${ }^{\circledR}-1$ fused silica capillary column $(30 \mathrm{~m} \times 0.32 \mathrm{~mm}$ I.D. with $1 \mu \mathrm{m}$ film thickness, Restek, USA). The GC temperature program consisted of an initial temperature of $35^{\circ} \mathrm{C}$ for $5 \mathrm{~min}$, ramping to $50^{\circ} \mathrm{C}$ at $2{ }^{\circ} \mathrm{C} / \mathrm{min}$ and holding for $10 \mathrm{~min}$, ramping to $225^{\circ} \mathrm{C}$ at $10{ }^{\circ} \mathrm{C} / \mathrm{min}$ and holding for $15 \mathrm{~min}$, ramping at $260^{\circ} \mathrm{C}$ at $10^{\circ} \mathrm{C} / \mathrm{min}$ and holding for $15 \mathrm{~min}$. $p$-bromofluorobenzene was added as an internal standard.

\section{Results and Discussion}

\section{(1) Raw water characteristics and DOM} properties

The key parameters of raw waters are shown in Table 2. The raw waters from reservoirs, i.e. $\mathrm{CH} 1$, $\mathrm{CH} 2$ and $\mathrm{HA}$, had high DOC of 5.48-6.60 mg/L and high bromide concentrations, while the AR water, which represents surface water of mainland in J apan, had lower DOC of $1.02 \mathrm{mg} / \mathrm{L}$ and bromide concentration. The high SUVA 254 values (ca. 3.63-4.14 L/mg-m) of reservoir waters show that dominant DOM in these waters were aromatic compounds, which are originated from degraded terrestrial material $s^{33)}$, while the AR water had moderate SUVA 254 of $2.55 \mathrm{~L} / \mathrm{mg}-\mathrm{m}$. The high bromide concentrations in the reservoir waters might be derived from atmospherically transported sea salt ${ }^{33)}$.

The AR water had a lower DOC/DON ratio (ca. 7.3; calculated based on Table 2) than those of the reservoir waters (ca. 9.5-14.7). Similar to this result, Chang et al. (2013) ${ }^{34)}$ reported lower DOC/DON ratios for the effluent of sewage treatment plant than those for raw waters from eutrophic lake in Kinmen Island. Domestic sewage discharge, containing several nitrogenous compounds (e.g. amino acids, peptides), might contribute to the low DOC/DON ratio of the $A R$ water, collected from the downstream of A rakawa River, which runs through residential area nearby Tokyo.

Based on the UF fractionation, dominant DOM in the reservoir waters had molecular weights greater than $3 \mathrm{kDa}$, accounting for $68-71 \%$ of total DOC, whereas that of the $A R$ water was smaller than 3 $\mathrm{kDa}$ (ca. $74 \%$ of total DOC). 
Table 2 Water quality parameters of the raw waters.

\begin{tabular}{ccccccc}
\hline & $\mathrm{pH}$ & $\begin{array}{c}\mathrm{DOC} \\
(\mathrm{mg} / \mathrm{L})\end{array}$ & $\begin{array}{c}\mathrm{SUVA}_{254} \\
(\mathrm{~L} / \mathrm{mg}-\mathrm{m})\end{array}$ & $\begin{array}{c}\mathrm{DON} \\
(\mathrm{mg} / \mathrm{L})\end{array}$ & $\begin{array}{c}\text { DOM MW } \\
>3 \mathrm{kDa}\end{array}$ & $\begin{array}{c}\mathrm{Br} \\
(\mathrm{mg} / \mathrm{L})\end{array}$ \\
\hline $\mathrm{CH} 1$ & 7.4 & 5.63 & 4.14 & 0.42 & $71 \%$ & 0.26 \\
\hline $\mathrm{CH} 2$ & 8.2 & 6.60 & 4.14 & 0.45 & $68 \%$ & 0.20 \\
\hline $\mathrm{HA}$ & 7.9 & 5.48 & 3.63 & 0.58 & $69 \%$ & 0.17 \\
\hline $\mathrm{AR}$ & 7.4 & 1.02 & 2.55 & 0.14 & $26 \%$ & 0.04 \\
\hline
\end{tabular}

\section{(2) DOM removal by the hybrid MF processes}

Calculated hydraulic contact time with adsorbents is shown in Table 3. According to the Yang et al. $(2014)^{25)}$, the adsorption of DOM onto FH reached equilibrium within $5 \mathrm{~min}$, which is within the range of calculated hydraulic contact times in this study.

The removal efficiencies of DOC, DON and SUVA $_{254}$ by MF alone and the hybrid processes are shown in Fig. 2.

The effectiveness of the hybrid adsorption-MF processes were raw water specific. The DOC and DON removals by MF alone were insignificant except for the HA water. MF alone showed substantial removals of DOC and DON in the HA water, suggesting that a considerable amount of nitrogen-containing DOM in the HA water was retained by the membrane. This caused the severe membrane fouling and prolonged contact time in the HA water in the hybrid processes (Table 3).

As shown in Fig. 2, the FH+MF process removed $37-64 \%$ of total DOC in the $\mathrm{CH} 1, \mathrm{CH} 2$ and $\mathrm{HA}$ waters, while the $\mathrm{PAC}+\mathrm{MF}$ process showed relatively a lower removal efficiency of $15-36 \%$. This can be due to relatively fast adsorption of DOM by FH compared to that of PAC. The external surface area for adsorption increases as decreasing the particle size, leading to instant DOM adsorption onto the surface of $\mathrm{FH}$. In contrast, the PAC+MF process removed $\mathrm{DOC}$ in the $\mathrm{AR}$ water more effectively than the $\mathrm{FH}+\mathrm{MF}$ process. Lin et al. $(1999)^{35)}$ reported that PAC preferentially adsorbs small aromatic DOM with MW of ca. $0.3-17 \mathrm{kDa}$ because of its microporous character. High affinity of low MW DOM to PAC can explain the effective DOC removal in the AR water, where dominant DOM was smaller than $3 \mathrm{kDa}$.

The overall $\mathrm{UV}_{254}$ removals in the $\mathrm{FH}+\mathrm{MF}$ and PAC+MF systems were higher than the DOC removals. This can be due to the preferential adsorption of aromatic DOM on FH or PAC. Although no significant DOC removals by MF alone were observed in the $\mathrm{CH} 1, \mathrm{CH} 2$ and $\mathrm{AR}$ waters, $\mathrm{UV}_{254}$ absorbance declined by $12-16 \%$, probably due to the different principles and detection limits of these two analytical methods.
Table 3 Calculated hydraulic contact time ( $\mathrm{min}$ ) of the samples.

\begin{tabular}{ccccc}
\hline Treatment & CH1 & CH2 & HA & AR \\
\hline PAC+MF & 10.2 & 4.0 & 13.7 & 3.7 \\
\hline FH+MF & 6.0 & 6.3 & 15.4 & 6.4 \\
\hline
\end{tabular}

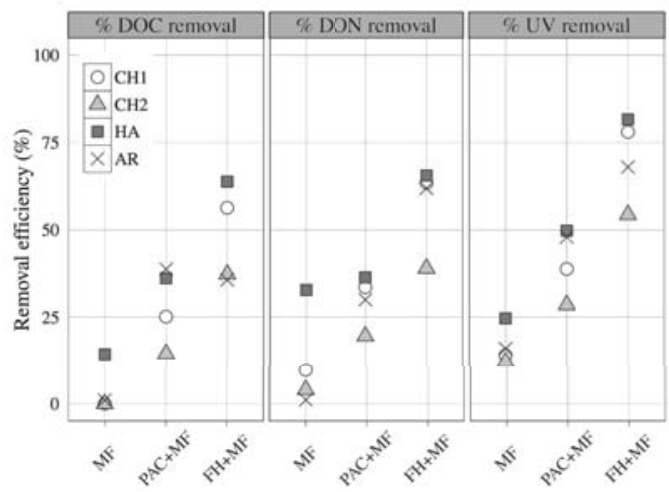

Fig. 2 Percent removal of DOC, DON and $\mathrm{UV}_{254}$ by MF and the hybrid MF processes.

\section{(3) DBPFP reduction by the hybrid MF processes}

THM and HAN concentrations of chlorinated raw and treated waters by the hybrid MF processes are presented in Fig. 3 (A) and (B), respectively.

\section{a) THM formation potential (THMFP)}

MF membrane alone could not remove the precursors of THMs efficiently, which conforms to a small DOC removal. FH+MF could mitigate THMFP considerably from $1.30-1.70$ to $0.44-0.90$ $\mu \mathrm{mol} / \mathrm{L}$ (ca. $44-66 \%$ reduction) in the $\mathrm{CH} 1, \mathrm{CH} 2$ and HA waters, but PAC+MF could reduce only to 0.91-1.66 $\mu \mathrm{mol} / \mathrm{L}$ (ca. 3-30 \%). Contrarily, in the AR water, PAC+MF achieved a comparable THMFP reduction with $\mathrm{FH}+\mathrm{MF}$, which is in line with the DOC removal. The different performance of the hybrid process among the waters might be due to the different DOM composition among them.

By FH+MF, the precursors of TCM $\left(\mathrm{CHCl}_{3}\right)$ and BDCM $\left(\mathrm{CHCl}_{2} \mathrm{Br}\right)$ in the reservoir waters were reduced from $0.88-1.24$ to $0.12-0.53 \mu \mathrm{mol} / \mathrm{L}$ for TCM and from $0.32-0.37$ to $0.14-0.28 \mu \mathrm{mol} / \mathrm{L}$ for BDCM, leading to the reduction in total THMFP. In contrast, the formation of brominated THMs (Br-THMs: DBCM $\left(\mathrm{CHClBr}_{2}\right)$ and TBM $\left(\mathrm{CHBr}_{3}\right)$ ) increased considerably in waters treated by $\mathrm{FH}+\mathrm{MF}$, even on a molar basis. The inability of $\mathrm{FH}$ and PAC to remove bromide increased the $\mathrm{Br} / \mathrm{DOC}$ ratio in treated waters, which contributes to higher formation of Br-THMs than untreated waters. Bromide ion can be readily oxidized into bromine $\left(\mathrm{HOBr} / \mathrm{OBr}^{-}\right)$when free chlorine exists in water. Hypobromous acid ( $\mathrm{HOBr}$ ) can halogenate THM precursors faster than hypochlorous acid ( $\mathrm{HOCl})$; hence, more $\mathrm{Br}$-THMs is produced even on a molar basis $^{36)}$. 


\section{b) HAN formation potential (HANFP)}

Significantly lower HANFPs were observed as compared to THMFPs (4.4-4.7\% of total THMFP in raw waters). The total molar concentration of HANs has been reported to be about $10 \%$ of the total molar THMs concentration, though it ranged from 2 to $20 \%$ depending on the water quality ${ }^{37)}$.

For the $\mathrm{CH} 1$ water, the $\mathrm{FH}+\mathrm{MF}$ process mitigated HAN formation by $65 \%$ (from 0.067 to 0.023 $\mu \mathrm{mol} / \mathrm{L}$ ) by removing DCAN precursors, whereas the PAC+MF process did not make a difference from $\mathrm{MF}$ alone or raw water. For the $\mathrm{CH} 2$ water, neither PAC nor FH adsorption had any effect in reducing HANFP, though significantly increased formation of DBAN was observed in water treated by the $\mathrm{FH}+\mathrm{MF}$ process. MF alone was effective to reduce HANFP in HA water by reducing TCAN and DCAN production. As discussed in Section 3 (2), MF alone rejected nitrogen-containing DOM in the HA water, indicating that these DOM rich in nitrogen are precursors of TCAN and DCAN. The $\mathrm{FH}+\mathrm{MF}$ process was less effective in removing DCAN precursors (50 \%: from 0.010 to 0.005 $\mu \mathrm{mol} / \mathrm{L}$ ) compared to the PAC+MF process, which removed $66 \%$ (from 0.010 to $0.003 \mu \mathrm{mol} / \mathrm{L}$ ) of DCAN precursors in the AR water.

DBAN formation after chlorination of waters treated by the $\mathrm{FH}+\mathrm{MF}$ process increased significantly, which is similar to the behavior of Br-THMs. It has been reported that DBAN formation potential increased by enhanced coagulation with PAC treatment probably due to the high $\mathrm{Br} / \mathrm{DOC}$ ratio $^{8}$.

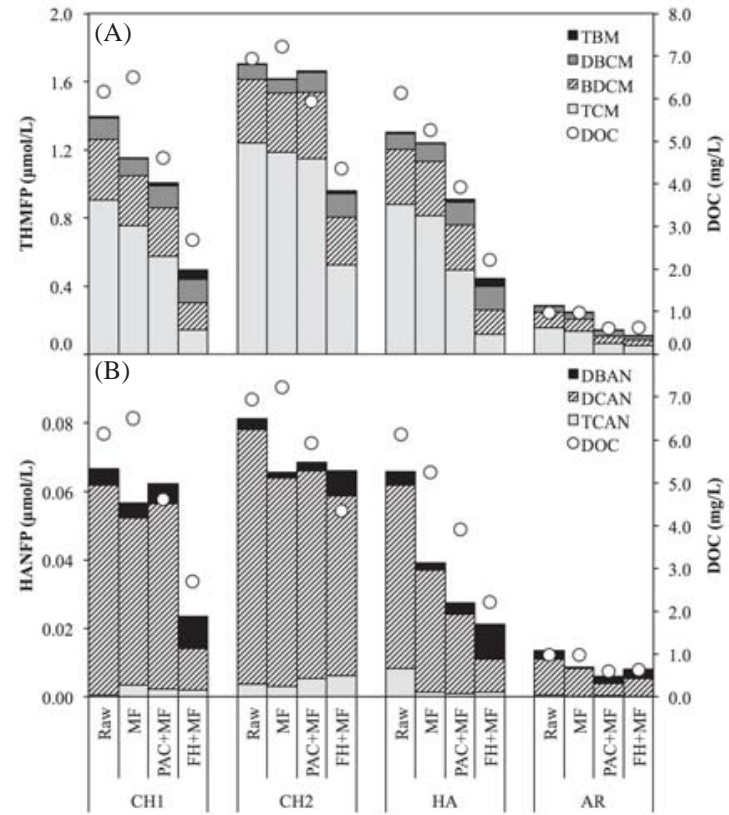

Fig. 3 (A) THMFP and (B) HANFP of raw and treated waters by the hybrid MF processes.

\section{(4) DBP YIELDS OF DOM}

Yields of each THM and HAN species for raw and treated waters, calculated on a molar basis by normalizing THM or HAN concentration with DOC concentration, are presented in Figs. 4 and 5, respectively.

a) THM yields

Apparently, the hybrid processes could remove DOM fractions with a high TCM yield, particularly in the $\mathrm{CH} 1$ and $\mathrm{HA}$ waters with $\mathrm{FH}+\mathrm{MF}$. It has been reported that hydrophobic acid DOM was the largest contributor of THM precursors in reservoir waters of the same sampling locations ${ }^{32)}$.

Contrarily, DOM fractions that remained after the treatment by the hybrid MF processes had a similar BDCM yield to, but greater DBCM and TBM yields than the raw water samples. FH has a high affinity of adsorption to hydrophobic, aromatic and large MW DOM, which is evidenced by the significant removal of $\mathrm{SUVA}_{254}$ as shown in Fig. 2. Therefore, DOM remaining after FH adsorption was likely to be hydrophilic or aliphatic fraction, which is reported to be more reactive against $\mathrm{HOBr}$ to produce $\mathrm{Br}-\mathrm{THMs}$ than hydrophobic fraction ${ }^{38)}$.

In the AR water, however, DOM remaining after the adsorption by $\mathrm{FH}$ yielded less brominated species compared to PAC-treated DOM, although $\mathrm{Br} / \mathrm{DOC}$ ratios after treatment were comparable (0.07 and 0.06 , respectively). $\mathrm{The} \mathrm{Br} / \mathrm{Cl}$ ratio was also comparable (0.028 and 0.027 , respectively). Thus, it was indicated that we need further studies on the causes of different results of brominated DBP formation by AR water from the others

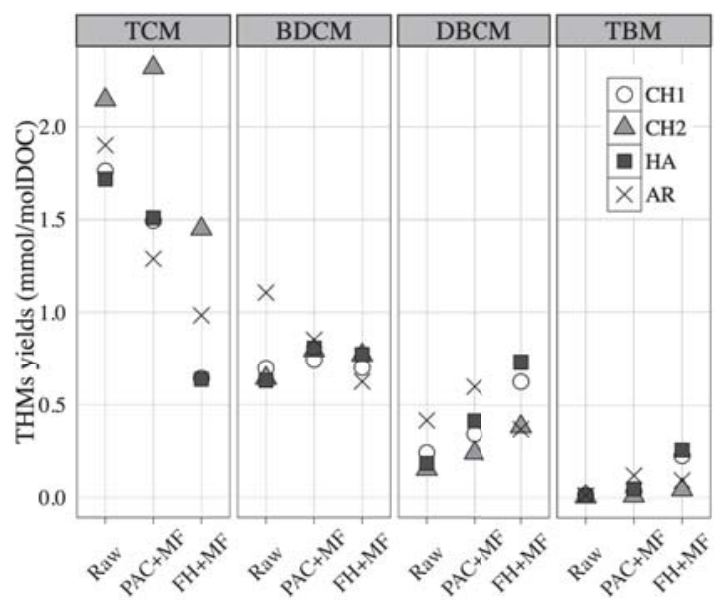

Fig. 4 Yields of each THM species of the raw and treated waters.

\section{b) HAN yields}

Since we applied chlorination, not chloramination in this research, nitrogen in HANs formed after 
chlorination should be originated from organic nitrogen. DON in water is reported to be mainly composed of degraded amino sugars, peptides and porphyrins ${ }^{39)}$. As shown in Fig. 6, significant positive correlation between DON and $\mathrm{SUVA}_{254}$ was observed in the $\mathrm{CH} 1, \mathrm{CH} 2$ and $\mathrm{HA}$ waters, suggesting that aromatic DON is dominant in the reservoir waters. The FH+MF process effectively removed these aromatic DOM by ligand exchange between the hydroxyl groups on FH surface and the carboxylic or phenolic groups on aromatic DOM surface $^{18)}$, resulting in the significant reduction of DCAN yields in the $\mathrm{CH} 1$ and $\mathrm{HA}$ water.

The yield of DCAN followed that of TCM for the $\mathrm{CH} 1$, and HA waters, whereas a different trend was observed with the $\mathrm{CH} 2$ water (Fig. 5), probably influenced by relatively low DOC removals by $\mathrm{PAC}+\mathrm{MF}$ and $\mathrm{FH}+\mathrm{MF}$ (Fig. 3).

Relatively low MW hydrophilic DOM was dominant in the AR water, which was effectively removed by PAC adsorption due to its small pore $\operatorname{size}^{35)}$. The contribution of hydrophilic DOM to the formation of DCAN is reported to be significant ${ }^{40)}$, resulting in lower DCAN yield after the PAC+MF treatment compared to the $\mathrm{FH}+\mathrm{MF}$ treatment in the AR water.

DBAN yield followed the same trend as Br-THMs in all waters. The increased yields of DBAN can be contributed to the increased Br/DOC ratio due to the inability of bromide removal by hybrid processs ${ }^{8)}$.

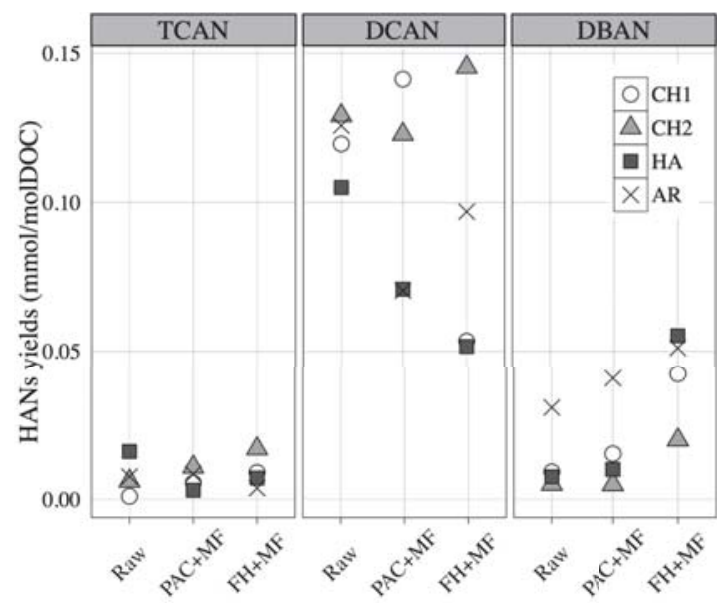

Fig. 5 Yields of each HAN species of the raw and treated waters

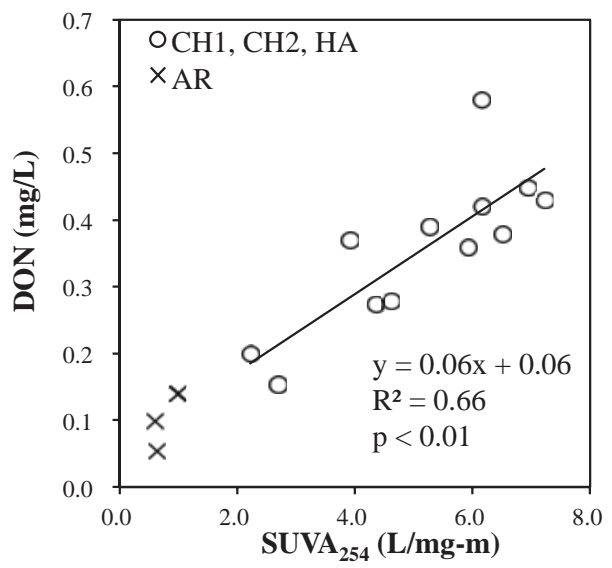

Fig. 6 Correlation between DON and $\mathrm{SUVA}_{254}$ of raw and treated waters. (Black line is the regression line of the $\mathrm{CH} 1$, $\mathrm{CH} 2$ and HA waters)

\section{(5) The formation of Br-DBPs}

The bromine incorporation factor (BIF) is commonly used to quantitatively evaluate the bromine incorporation into DBPs. BIF of THMs $(n)$ and HANs $\left(n^{\prime}\right)$ is calculated by the following equations ${ }^{5}$ :

For THMs,

$n=\frac{0 \times\left[\mathrm{CHCl}_{3}\right]+1 \times\left[\mathrm{CHCl}_{2} \mathrm{Br}\right]+2 \times\left[\mathrm{CHClBr}_{2}\right]+3 \times\left[\mathrm{CHBr}_{3}\right]}{\left[\mathrm{CHCl}_{3}\right]+\left[\mathrm{CHCl}_{2} \mathrm{Br}\right]+\left[\mathrm{CHClBr}_{2}\right]+\left[\mathrm{CHBr}_{3}\right]}$

For HANs,

$$
n^{\prime}=\frac{0 \times\left[\mathrm{CCl}_{3} \mathrm{CN}\right]+0 \times\left[\mathrm{CHCl}_{2} \mathrm{CN}\right]+2 \times\left[\mathrm{CHBr}_{2} \mathrm{CN}\right]}{\left[\mathrm{CCl}_{3} \mathrm{CN}\right]+\left[\mathrm{CHCl}_{2} \mathrm{CN}\right]+\left[\mathrm{CHBr}_{2} \mathrm{CN}\right]}
$$

where the DBPs concentrations are on a molar basis.

BIF and $\mathrm{SUVA}_{254}$ are plotted in Fig. 7. SUVA 254 correlated significantly with THMs and HANs bromine incorporation factors of the reservoir waters $\left(R^{2}=0.83, p<0.01\right.$ for THMs, $R^{2}=0.78, p<$ 0.01 for HANs, respectively). As SUVA $_{254}$ increased, BIF decreased, implying that bromine is more effectively incorporated into low $\mathrm{SUVA}_{254}$ fractions (i.e. aliphatic or hydrophilic fractions). This relationship between BIF and $\mathrm{SUVA}_{254}$ explains the reason of the increased Br-DBPs yields after $\mathrm{FH}+\mathrm{MF}$ treatment: $\mathrm{FH}$ cannot effectively adsorb low $\mathrm{SUVA}_{254}$ fractions, which readily incorporate bromine to produce Br-DBPs. In addition, a recent publication has revealed that structures such as hydroquinone and phenolic groups, which are abundant in humic substances ${ }^{6}$ (DOM fractions with high $\mathrm{SUVA}_{254}$ ), prefer reaction with bromine via electron transfer (i.e. oxidation) rather than the bromine incorporation ${ }^{9}$.

The BIF of THMs $(n)$ was higher than that of HANs $\left(n^{\prime}\right)$ in all waters, indicating preference of bromine incorporation into THMs compared to 
HANs. Kitis et al. (2002) ${ }^{13)}$ observed lower BIF of HAAs than that of THMs with waters of identical SUVA $_{254}$ value. Since HAAs have complicated structure (i.e. carboxyl group) compared to THMs, bromine incorporation might be disturbed due to structural hindrance. The cyanide group in HANs might be the obstacle for bromine incorporation, thus resulting in lower BIF than that of THMs.

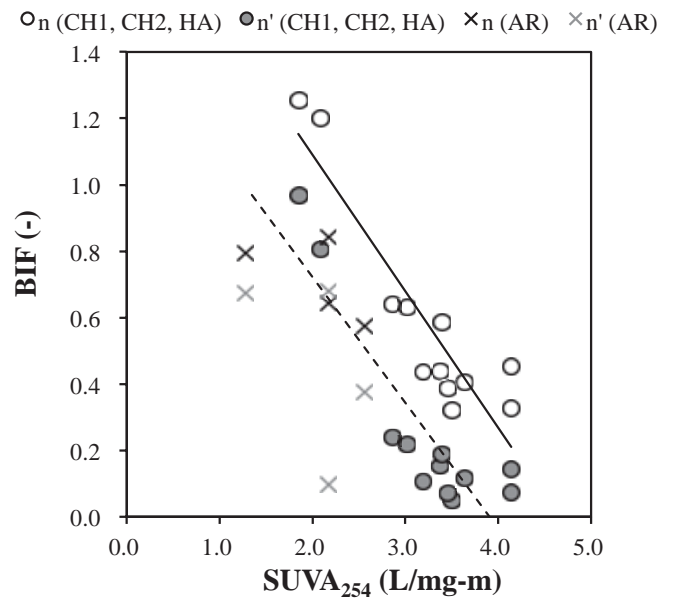

Fig. 7 Correlation between BIF and SUVA $_{254}$ of raw and treated waters (Black line and dashed line represent the regression line $\mathrm{n}$ and $\mathrm{n}^{\prime}$ of the $\mathrm{CH} 1, \mathrm{CH} 2$ and $\mathrm{HA}$ waters, respectively)

\section{CONCLUSIONS}

Conclusions can be addressed from this study as follows:

- A hybrid $\mathrm{FH}+\mathrm{MF}$ process eliminated THMFP and HANFP by mainly removing the precursors of chlorinated DBPs, while formation of brominated species increased due to the inability of $\mathrm{FH}$ in removing bromide.

- $\mathrm{FH}+\mathrm{MF}$ process was less effective in removing low MW hydrophilic DOM than PAC+MF process, thus yielding more DCAN formation after chlorinating the treated waters.

- Despite different sources of raw water and treatment methods that were applied to them, there was fairly good correlation between SUVA $_{254}$ and BIF, which can be used to explain increased Br-DBPs yields after $\mathrm{FH}+\mathrm{MF}$ treatment.

- DBPs with a simple structure, namely THMs appeared to be effectively substituted with bromine compared to those having more complicated structures, e.g. HANs.
ACKNOWLEDGEMENT: This work was supported by JSPS Grant-in-aid for Scientific Research No. 26820221.

\section{REFERENCES}

1) Morris, R. D., Audet, A. M., Angelillo, I. F., Chalmers, T. C. \& Mosteller, F. : Chlorination, chlorination by-products, and cancer: a meta-analysis, Am. J. Public Health, Vol. 82, No. 7, pp. 955-63, 1992.

2) Sun, Y. X., Wu, Q. Y., Hu, H. Y.\& Tian, J. : Effect of bromide on the formation of disinfection by-products during wastewater chlorination, Water Res. Vol. 43, No.9, pp. 2391-2398, 2009.

3) Uyak, V. \& Toroz, I. : Investigation of bromide ion effects on disinfection by-products formation and speciation in an Istanbul water supply, J. Hazard. Mater., Vol. 149, No.2, pp. 445-451, 2007.

4) Muellner, M. G., Wagner, E. D., Mccalla, K. \& Richardson, S. D. : Haloacetonitriles vs . Regulated Haloacetic Acids : Are Nitrogen-Containing DBPs More Toxic ?, Environ. Sci. Technol., Vol. 41, No.2, pp. 645-651, 2007.

5) Symons, J. M., Krasner, S. W., Simms, L. A. \& Sclimenti, M. : Measurement of THM and precursor concentrations revisited - the effect of bromide ion, J. Am. Water Work. Assoc., Vol. 85, No.1, pp. 51-62, 1993.

6) Croue, J. P., Korshin, V. G. \& Benjamin, M. M. : Characterization of Natural Organic Matter in Drinking Water, American Water Works Association Research Foundation, 2000.

7) Xie, Y. : DISINFECTION BYPRODUCTS in DRINKING WATER Formation, Analysis and Control, LEWIS PUBLISHERS, 2004.

8) Watson, K., Farre, M. J. \& Knight, N. : Enhanced coagulation with powdered activated carbon or MIEX® secondary treatment: A comparison of disinfection by-product formation and precursor removal, Water Res., Vol. 68, pp. 454-466, 2015.

9) Criquet, J. et al. : Reaction of bromine and chlorine with phenolic compounds and natural organic matter extracts e Electrophilic aromatic substitution and oxidation, Water Res., Vol. 85, pp. 476-486, 2015.

10) Reckhow, D. a, Singer, P. C. \& Malcolm, R. L. Chlorination of humic materials: Byproduct formation and chemical interpretations, Environ. Sci. Technol., Vol. 24, No. 11, pp. 1655-1664, 1990.

11) Imai, A., Matsushige, K. \& Nagai, T. : Trihalomethane formation potential of dissolved organic matter in a shallow eutrophic lake, Water Res., Vol. 37, pp. 4284-4294, 2003.

12) Nagai, K., Aoki, S., Fuse, Y. \& Yamada, E. : Fractionation of Dissolved Organic Matter (DOM) as Precursors of Trihalomethane in Lake Biwa and Yodo Rivers, Bunseki Kagaku, Vol. 54, No.9, pp. 923-928, 2005.

13) Kitis, M., Karanfil, T., Wigton, A. \& Kilduff, J. E. : Probing reactivity of dissolved organic matter for disinfection by-product formation using XAD-8 resin adsorption and ultrafiltration fractionation, Water Res., Vol. 36, No.15, pp. 3834-3848, 2002. 
14) Ates, N., Kitis, M. \& Yetis, U. : Formation of chlorination by-products in waters with low SUVA-correlations with SUVA and differential UV spectroscopy, Water Res., Vol. 41, No.18, pp. 4139-4148, 2007.

15) Hua, G., Reckhow, D. A. \& Abusallout, I. : Correlation between SUVA and DBP formation during chlorination and chloramination of NOM fractions from different sources, Chemosphere, Vol. 130, pp. 82-89, 2015.

16) Michel, F. M. et al. : The structure of ferrihydrite, a nanocrystalline material, Science, Vol. 316, No. 5832, pp. 1726-1729, 2007.

17) Rout, K., Mohapatra, M. \& Anand, S. : 2-line ferrihydrite: synthesis, characterization and its adsorption behaviour for removal of $\mathrm{Pb}(\mathrm{II}), \mathrm{Cd}(\mathrm{II}), \mathrm{Cu}(\mathrm{II})$ and $\mathrm{Zn}$ (II) from aqueous solutions, Dalton Trans., Vol. 41, No.41, pp. 3302-3312, 2012.

18) Yang, Y., Takizawa, S., Sakai, H., Murakami, M. \& Watanabe, N. : Removal of organic matter and phosphate using ferrihydrite for reduction of microbial regrowth potential, Water Sci. Technol., Vol. 66, No.6, pp. 1348-1353, 2012 .

19) Campinas, M. \& Rosa, M. J. : Assessing PAC contribution to the NOM fouling control in PAC/UF systems, Water Res., Vol. 44, No.5, pp. 1636-1644, 2010.

20) Mavrov, V. et al. : Comparative study of different MF and UF membranes for drinking water production, Desalination, Vol. 117, pp. 189-196, 1998.

21) Lebeau, T. et al. : Immersed membrane filtration for the production of drinking water: combination with PAC for NOM and SOCs removal, Desalination, Vol. 117, pp. 219-231, 1998.

22) Zhang, W., Zhang, X. J., Li, Y. H., Wang, J. \& Chen, C. Membrane flux dynamics in the submerged ultrafiltration hybrid treatment process during particle and natural organic matter removal, J. Environ. Sci., Vol. 23, No. 12, pp. 1970-1976, 2011.

23) Lohwacharin, J. \& Takizawa, S. : Effects of nanoparticles on the ultrafiltration of surface water, J. Memb. Sci., Vol. 326, pp. 354-362, 2009.

24) Leone, P., Gennari, M., Nègre, M. \& Boero, V. : Role of ferrihydrite in adsorption of three imidazolinone herbicides, J. Agric. Food Chem., Vol. 49, No.3, pp. 1315-1320, 2001.

25) Yang, Y., Lohwacharin, J. \& Takizawa, S. : Hybrid ferrihydrite-MF/UF membrane filtration for the simultaneous removal of dissolved organic matter and phosphate, Water Res., Vol. 65, pp. 177-185, 2014.

26) APHA. Standard Methods for the Examination of Water and Wastewater, American Public Health Association, 2005.

27) Lohwacharin, J., Oguma, K. \& Takizawa, S. : Use of carbon black nanoparticles to mitigate membrane fouling in ultrafiltration of river water, Sep. Purif. Technol., Vol. 72, No.1, pp. 61-69, 2010.
28) Kang, S.-K. \& Choo, K.-H. : Why does a mineral oxide adsorbent control fouling better than powdered activated carbon in hybrid ultrafiltration water treatment?, J. Memb. Sci., Vol. 355, pp. 69-77, 2010

29) Lohwacharin, J., Oguma, K. \& Takizawa, S. : Ultrafiltration of natural organic matter and black carbon : Factors influencing aggregation and membrane fouling, Water Res., Vol. 43, No. 12, pp. 3076-3085, 2009.

30) JWWA. Standard Methods for the examination of Water (in Japanese), 2011

31) U.S. Environmental Protection Agency: Method 551.1: Determination of chlorination disinfection byproducts, chlorinated solvents, and halogenated pesticides/herbicides in drinking water by liquid-liquid extraction and gas chromatography with electron-capture detection, 1995.

32) Phetrak, A., Lohwacharin, J. \& Takizawa, S. : Analysis of trihalomethane precursor removal from sub-tropical reservoir waters by a magnetic ion exchange resin using a combined method of chloride concentration variation and surrogate organic molecules, Sci. Total Environ., Vol. 539, pp. $165-174,2016$

33) Tochimoto, H. et al. : Quality of Raw Water for Drinking-Water Supply on the Ogasawara Islands -Focusing on Formation Potentials of Disinfection By-products, $J$. Japan Soc. Water Environ., Vol. 33, No.11, pp. 181-191, 2010.

34) Chang, H., Chen, C. \& Wang, G. : Characteristics of CN-DBPs formation from nitrogen-enriched dissolved organic matter in raw water and treated wastewater effluent, Water Res., Vol. 47, No.8, pp. 2729-2741, 2013.

35) Lin, C. F., Huang, Y. J. \& Hao, O. J. : Ultrafiltration processes for removing humic substances: Effect of molecular weight fractions and PAC treatment, Water Res. Vol. 33, No.5, pp. 1252-1264, 1999.

36) Tian, C. et al. : Chlorination and chloramination of high-bromide natural water: DBPs species transformation, Sep. Purif. Technol., Vol. 102, pp. 86-93, 2013.

37) Oliver, B. : Dihaloacetonitriles in Drinking Water: Algae and Fulvic Acid as Precursors, Environ. Sci. Technol., Vol. 17, No. 2, pp. 80-83, 1983.

38) Liang, L. \& Singer, P. C. : Factors influencing the formation and relative distribution of haloacetic acids and trihalomethanes in drinking water, Environ. Sci. Technol. Vol. 37, No.13, pp. 2920-2928, 2003.

39) Leenheer, J. A. : Comprehensive assessment of precursors, diagenesis, and reactivity to water treatment of dissolved and colloidal organic matter, Water Sci. Technol. Water Supply, Vol. 4, No.4, pp. 1-9, 2004.

40) Lee, W., Westerhoff, P. \& Croue, J. : Dissolved Organic Nitrogen as a Precursor for Chloroform, Dichloroacetonitrile, N-Nitrosodimethylamine, and Trichloronitromethane, Environ. Sci. Technol., Vol. 41, No.15, pp. 5485-5490, 2007.

(Received May 26, 2016) 